\title{
Antecedents and Consequences of Employee Engagement: A Conceptual Study
}

\author{
Alima Aktar ${ }^{1}$, Faizuniah Pangil ${ }^{2}$ \\ ${ }^{1}$ PhD candidate, School of Business Management, Universiti Utara Malaysia (UUM) \\ ${ }^{2}$ Associate Professor, School of Business Management, Universiti Utara Malaysia (UUM)
}

\begin{abstract}
Employee engagement is a psychological state of mind of doing the work with full of energy, enthusiasm and dedication which can provide the competitive advantage of an organization. The purpose of this paper is to synthesize prior literature to identify antecedents and consequences of employee engagement. This literature review shows that prior studies examined diverse types of antecedences as well as consequences of employee engagement. Results of these existing studies are varied and inconclusive which leads the importance of further study in order to enhance the clarity of the relationship of employee engagement with its antecedents and consequences.
\end{abstract}

Keywords: Employee Engagement; Job Characteristics; Organizational Practices; Personal Traits; Individual Outcome; Organizational Outcome.

\section{Introduction}

Employee engagement is a burning issue in human resource development field (Wollard \& Shuck, 2011) due to its critical in achieving organizational success and competitiveness (Gruman \& Saks, 2011; Macey et al., 2009)). Indeed, engaged employees can significantly contribute to organizational performances (Demerouti \& Cropanzano, 2010). Prior studies showed a positive influence of employee engagement on employee attitude, behavior and performance such as job satisfaction (Hakanen\&Schaufeli, 2012); work ability (Bakker et al., 2012) and innovative behavior (Slatten\&Mehmetoglu, 2011) and negative influence on turnover intention (Agarwal et al., 2012); deviant behavior (Shantz et al., 2014) and absenteeism (Schaufeli et al., 2004). Consequently, an emerging trend of research on employee engagement can be observed in last two decades (Albrecht \& et. al., 2015). In spite of the recognized importance of engagement along with the emerging research trend, existing research found the low level of engagement among employees (Richman, 2006; Bates, 2004). For example, Gallup's survey (2012) reported that $63 \%$ of employees around the world are not engaged at their job. In this context, this is crucial to explore the exiting literature on employee engagement in order to enhance our understanding about what are the driving factors of employee engagement and how does employee engagement lead organizational performance. This current paper, therefore, attempts to identify the antecedents and consequences of employee engagement for enhancing the understanding about the dynamic of employee engagement in organizational context.

\section{Concept of Employee Engagement}

The concept of engagement began to surface in the organizational and business literature around two decade ego (Simpson, 2009). Schaufeli et al. (2008) demonstrated that the concept of engagement has emerged from burnout literature as an effort to examine not only employees unwell-being but also to understand wellbeing of employees. In contrary to the employees who experience burnout, engaged employees feel capable enough to fulfill the assigned tasks as they are more energetic and connected to their work (Schaufeli et al., 2008). One of the challenges of defining engagement is the lack of a universal definition of employee engagement. In the existing literature, employee engagement is defined and explained by different individuals and organizations from different perspectives. Though the concept of engagement has received a great lead of attention recently both in research and practice, different parties use different items and scale to measure the term (Robertson \& Cooper, 2010). Therefore, we discuss these to understand the concept of engagement in a comprehensive way.

For the first time in the academic literature, employee engagement appears in an Academy of Management journal article as "Psychological Conditions of Personal Engagement and Disengagement at Work" (Kahn, 1990). He inspired by Goffman's (1961) sociology text "The Presentation of Self in Everyday Life" and suggested that "people act out monetary attachments and detachments in their role performances" (Kahn, 1990, p. 694). Kahn (1990) defined personal engagement as the "harshening of organization members' selves to their work roles; in engagement, people employ and express themselves physically, cognitively, and emotionally during role performance". On the other hand, personal disengagement refers to "the uncoupling of selves from work roles; in disengagement, people withdraw and defend themselves physically, cognitively and 
emotionally during role performance" (p. 694). He identified three psychological conditions which stimulate employees to engage in their works by enhancing the contact between employees and their works. These are: psychological meaningfulness i.e., how meaningful is it for an employee to bring himself into the performance?, psychological safety i.e., how safe is it to do so?, and psychological availability i.e., how available is he to do so? Kahn (1990) further described that "personal engagement is the simultaneous employment and expression of a person's "preferred self" in task behaviors that promote connections to work and to others, personal presence (physical, cognitive, and emotional) and active, full role performances (p. 700). Thus, engaged employees are physically involved in their tasks, are cognitively alert and attentive, and are emotionally connected to their works and to others and in the workplaces. In other words, engagement refers to how psychologically present employees are behaving during certain moments in their role performances. According to Kahn (1990), individuals who are more likely to draw upon themselves within boundaries between them and their roles what they occupy to perform their jobs, they feel more inspire to perform their roles and more content they are to play those roles. Taken together from the work of Goffman (1961), Maslow et al., (1970), and Alderfer (1972), Kahn (1990) suggested that, to understand what makes a person engaged in their jobs, it is very important to understand the dimensions of meaningfulness (work elements), safety (social elements including management style, process and organizational norms), and availability (distractions) (p. 705). In summary, according to Kahn (1990, 1992), engagement means the individual who psychologically present at work when performing an organizational role.

The only study to date, May et al. (2004) empirically tested Kahn's (1990) model and found that all the three components of conceptualization of employee engagement were important in employee engagement. This study also posited that engagement is the combination of both cognitive and emotional work and work activities experiences which make an individual behave while performing a job (May et al., 2004). Rothbard (2001) extended Kahn's (1990) work and defined employee engagement as psychological presence of employees during performing their work. However, he extended the notion of prior definition by suggesting two critical components of engagement such as attention and absorption of employees. Therefore, employee engagement defined as the psychological presence at a particular work role that involves attention and absorption (Bakker \& Schaufeli, 2008; Saks, 2006).

Another group of academic researchers focusing on burnout concept treat employee engagement as the opposite of burnout (Maslach \& Leiter, 1997; Maslach et al., 2001). They identified that core dimensions of burnout (exhaustion and cynicism) and engagement (vigor and dedication) are opposites of each other (Gonzalez-Roma et al., 2006). Scholars state engagement as the opposite of three components of burnout dimensions: exhaustion, cynicism, and sense of inefficacy (Shuck, 2010; Gonzalez-Roma et al., 2006). Therefore, burnout termed as "erosion of engagement with the job" (Maslach et al., 2001, p. 416) and burnout measurement scale called Maslach Burnout Index (MBI) can be used to measure the level of engagement. By using that scale, one can understand that how an engaged employee could be connected with their job positively and energetically and can handle the demands of their job (Schaufeli et al., 2002). However, although the definition of engagement has been developed by the burnout research, assuming that burnout and engagement are the two different side of a coin, may not be acceptable, and in other research, they conceptualized these two different concepts by using a single instrument i.e. MBI (Schaufeli \& Bakker, 2004; Schaufeli et al., 2002).

In line with this approach, Schaufeli et al. (2002, p. 74) define that employee engagement is a positive, fulfilling, work-related state of mind that is characterized by vigor, dedication, and absorption. Vigor means high level of energy and mental resilience of employees, while dedication refers to enthusiasm of employees. In addition, absorption means full concentration of employees during the work. They also asserted that engagement is not a momentary state rather a more persistent and pervasive affective-cognitive state. There are numerous definitions of employee engagement has been derived by several scholars from different perspectives. For example, Harter et al. (2002) defined employee engagement as "the individuals" involvement and satisfaction with as well as enthusiasm for work (p. 269). Perrin's Global Workforce study termed employee engagement "as employees willingness and ability to company success by incorporating discretionary effort into their work, in the form of extra time, brainpower and energy" (Towers Perrin, 2003, p. 1). Hewitt Associates LLC (2004, p. 2) cited it as "the state in which individuals are emotionally and intellectually committed to the organization or group, as measured by three primary behaviors: Say [...], Stay [...] and Strive". Institute of employment studies stated engagement as "a positive attitude held by the employee towards the organization and its value. An engaged employee is aware of business context, and works with colleagues to improve performance within the job for the benefit of the organization. An organization should develop and nurture engagement, which requires a two-way relationship between employer and employee" (Robinson et al., 2004, p. 9).

In the academic literature, Saks (2006) provided an important bridge between previous theories of employee engagement, practitioner literature, and the academic community. He theorized the employee engagement through a social exchange model and was the first who separated employee engagement as job engagement and organization engagement. Thus, Saks (2006) defined engagement as "a distinct and unique 
construct consisting of cognitive, emotional, and behavioral components......associated with individual role performance (p. 602). However, engagement is a psychological state or mood in which an individual is engrossed not with the organization but in a performance of the work role (Saks, 2006; Ferrer, 2005). Ferrer (2005) also noted that attitudes are constant or stable over time but psychological state or mood fluctuates. Another professional body, followed by Kahn's (1990) three dimensions of employee engagement as emotional engagement, "being very involved emotionally with one's work"; cognitive engagement "focusing very hard while at work"; and physical engagement "being willing to go the extra mile for your employer" (CIPD, 2006, p.2). They also summarize employee engagement as a psychological state, a "passion for work" (p. 2).

In 2008, the American Society for training and Development (ASTD) defined engagement as "employees who are mentally and emotionally invested in their work and in contributing to their employer's success" (Czarnowsky, 2008, p. 6). Another perspective of employee engagement has developed by Macey and Schneider (2008) by conceptualizing engagement as trait engagement, state engagement, and behavioral engagement. From their perspective, employee engagement is defined by suggesting that "(a) job design attributes would directly affect trait management, (b) the presence of a transformational leader would directly affect state management, and (c) the presence of a transformational leader would directly affect trust levels and thus, indirectly affect behavioral engagement" (Macey \& Schneider, 2008, p. 25). Compare to psychological and burnout perspective, Macey et al. (2009) promulgates a broader view of engagement and defines employee engagement as an overarching umbrella which contains different types of engagement such as personality trait engagement, work involvement and organizational citizenship behavior. Robertson et al. (2012) argue that this perspective of engagement is much more inclusive and broader than the psychological view. In another study, Macey et al. (2009) posited engagement as "an individual's sense of purpose and focused energy, evident to others in the display of personal initiative, adaptability, effort, and persistence directed toward organizational goals" (p. 7). After the process of synthesizing definitions and conceptual frameworks of employee engagement, Schaufeli and Bakker (2010, p. 22) located engagement as a mediating variable in their job demands and resources model of work motivation and termed engagement as "the psychological state that accompanies behavioral investment of personal energy". According to Shuck and Wollard (2010), employee engagement is "an individual employee's cognitive, emotional, and behavioral state directed toward desired organizational outcomes" (p. 103). Albrecht (2010) has coined employee engagement as "a positive work-related psychological state characterized by a genuine willingness to contribute to organizational success" (p. 5). Scholars grounded employee engagement as an employee's unique experiences of work and behavioral aspects that include their cognitive and emotional interpretation of work-related environmental inputs and outputs (Shuck et al., 2011). A Gallup Management study described that engaged employees "are deeply committed to their employer, leading to key improvements in business outcomes, including reductions in absenteeism, turnover, shrinkage, safety incidents, and product defects" (Robinson 2012, p. 1). Furthermore, Alfes et al (2013) cited that work engagement is a "multi-dimensional latent motivational construct" (p. 2610).

In brief, the literature review suggests that employee engagement has been conceptualized in many different ways. Thus, it becomes very difficult to conceptualize employee engagement universally because of various existing concepts of engagement, which have been derived under a different protocol, using different measures of engagement under different circumstances. In spite of this potential problem, a similar pattern has been found, regardless of the country or context, that employee engagement is the extent to which employees are motivated to involve in work physically and psychologically so that they can give their best to achieve organizational goal.

\section{Psychological Contract Model}

\section{Employee Engagement Models}

Kahn (1990), for the first time, promulgates the Psychological Contract Theory (PCT) highlighting the specific psychological conditions essential for magnify the level of employee engagement. According to him, three psychological conditions are crucial for motivating employees to engage more. These are psychological meaningfulness, psychological safety, and psychological availability. The arguments of PCT is similar like SET that if organizations can ensure these three psychological conditions, in exchange, employee are tend to higher level of engage at their work. However, unlike PCT, specification of these three psychological conditions by PCT enhances the implication of PCT to explain the impact of HRM practices on employee engagement.

\section{Job-Demand Resource Model}

According to Job-Demand Resource Theory (JD-R), psychological contracts fulfillment acts as a job resources that enhances employee engagement (Parzefall \& Hakanen, 2010). JD-R argues that though employees sometimes expect to engage at work personally, they cannot produce engagement due to absent of favorable condition in the work environment. This model further explains that employees who receive resources such as supervisory coaching and support from organizations are more likely to engage (Hakanen et al., 2006), and can provide superior service performance (e.g., providing prompt service, identifying product fitted with customers' need). 


\section{Antecedents of Employee Engagement}

The search for the antecedents of employee engagement is relatively new (Slatten \& Mehmetoglu, 2011; Macey et al., 2009). Researchers have identified that several literature of employee engagement has come from practitioner and consultant but still a dearth of academic research of employee engagement has been realized (Robinson et al., 2004). Though various studies trying to find out the understanding of what drives employee engagement, the literature on antecedents or drivers of employee engagement does not represent a lot of empirical research (Saks, 2006). This section presents the current thinking and evidence of the catalyst for employee engagement.

To identify the possible antecedents of engagement, Saks (2006), based on the models by Kahn (1990) and Maslach et al. (2001), considers job characteristics, Perceived Organizational Support (POS), perceived supervisory support, rewards and recognition, procedural justice and distributive justice as the antecedents of engagement. Further, Saks (2006) found a distinction between two types of engagement, job engagement and organization engagement in which the antecedents might differ. Jobs which are high on the core job characteristics give individuals with the room and motivation to bring themselves more into their work or to be more engaged (Kahn, 1992). Saks (2006) took a sample of 102 employees working in different jobs and organizations in Canada and the experience in their current job an average of four years. Results showed that job characteristics was significant predictors of job engagement where POS had the significance influence on both job and organization engagement but procedural justice was the significance predictor of organization engagement. However, Shantz et al. (2013) have tried to ascertain the drivers of employee engagement with a sample of 283 employees in the UK by incorporating the Hackman and Oldham's (1980) classic Job Characteristics Model (JCM), that identified five core job features as motivational properties of job: task variety, task identity, task significance, autonomy and feedback. Findings demonstrated that task variety was the strongest determinant of employee engagement. Moreover, autonomy, feedback and task significance had a positive association to engagement, but task identity was not positively related to engagement. Further Ghosh et al. (2014) extended the antecedents-consequences model proposed by Saks (2006) incorporating distributive, procedural and interactional justice as predictors of employee engagement considering both job engagement and organization engagement. In their study, they found distributive justice and interactional justice as significant antecedents for both job and organization engagement, while procedural justice was the significant predictor only for organization engagement. On the other hand, Findley et al. (2014) suggested that organizational strategic profit emphases affect job and organization engagement. They proposed that employees who think that their organization is providing supportive and work-related resources i.e. revenue enhancement strategic profit emphasis, they will be more engaged and dedicated to the work in repay of that. Alternatively, employees with inconsistent quality service i.e. cost containment strategic profit emphasis, will be less engaged (Ye et al., 2007). Results showed that both revenue enhancement and cost containment were significantly related to job engagement. While revenue enhancement was the stronger predictor of organization engagement, cost containment had no significant effect on organization engagement. Another study by Lee et al. (2014) observed that internal branding consisting three components: internal communication, training and reward might predict job and organizational engagement. Because employees will get clear guidance and direction to deliver brand messages and meaning to the customers through internal branding (Choi, 2006; Keller, 2003). Therefore, Lee et al. (2014) expected that employees with internal branding have a positive influence on how employees feel about their job. Based on the data collected from 367 services employees of hotels in South Korea, they found the significant and positive effect of internal branding on job and organization engagement. According to Lee et al. (2014), companies could achieve employee engagement through internal branding by improving the quality of internal communication, giving more training or rewarding the employees so that they will motivate to enhance their performance. Karatepe (2013) also argued that the high-performance work practices manifested by training, empowerment and rewards would create synergy in the organization and ultimately trigger the employee engagement. In the study with a sample of 110 full-time hotel employees in Romania, Karatepe (2013) found that training, empowerment and rewards were significantly and positively influenced work engagement.

Likely Saks (2006), Trinchero et al. (2013) examined that relationship of POS, training \& development and discretionary power with employee engagement based on a sample of 826 nurses in Italy. Findings showed that all the constructs were the important drivers of engagement which confirmed the importance of workplace relationships in enhancing autonomy and engagement as well. On the other hand, Brunetto et al. (2013) examined the workplace relationships namely POS, supervisor-nurse relationships and teamwork on engagement of 510 nurses from Australian and 718 nurses from USA hospitals. Their study found that though POS and teamwork were significant predictors of employee engagement for both Australia and USA, supervisor-subordinate relationships affected engagement in Australia, but not in USA. They argued that the relationships increased the discretionary power and thus supervisor had a greater influence on nurses' outcomes in Australia but the reforms had opposite effect on the outcomes of nurses in USA. In addition, Biswas and 
Bhatnagar (2013) examined POS and person-organization fit as the antecedents of work engagement with the sample of 246 Indian managers, and found that both POS and person-organization fit would be the significantly correlated with employee engagement. In another study by Caesens et al. (2014), based on $343 \mathrm{PhD}$ students, suggested that due to the lack of work-related support such as organizational support may create harm for the students' psychological and physical health.

In the academic literature, job factors such as job demands and job resources have come on the focus as the antecedents of employee engagement. Prior studies demonstrated that specific job characteristics could motivate individuals to be more engaged in their job. For example, Sarti (2014) with the sample of 167 caregivers in Italy revealed that learning opportunity was the significant and strongest driver of engagement, while financial rewards and feedback had no relation to work engagement. In addition, decision authority negatively but co-worker and supervisor support significantly associated with employee engagement. On the other hand, Albrecht (2012) incorporated three types of resources i.e. organizational, team and job resources in line with the job-demand resources model of work engagement by Bakker and Demerouti (2007) to examine their impact on engagement among 3437 employees of a multinational mining company. They found that organizational culture, team climate and job resources of supervisor coaching, career development, role clarity and autonomy had positive direct influence on employee engagement. These results suggested that the provision of job resources could work as an intrinsic motivation of employees and increased positive affect towards their work. Another study led by Taipale et al. (2011) among 7867 employees who were working in different sectors in 8 different European countries in 2007 and ascertained that job demands and resources predicted job engagement. Results pointed out that demands had lower negative impact on engagement for Finland, Sweden, Germany and Hungary, but no impact for Bulgaria, the Netherlands, Portugal and the UK. Work autonomy and social support were the strong predictors of work engagement, except for Bulgaria and Finland where social support had relatively low influence on engagement. Schaufeli and Bakker (2004) focused on the predictors of engagement and its negative antipode- burnout comprised a sample of 1698 employees working in four independent sectors. Findings indicated that both job demands as well as inadequate resources were the antecedents of burnout whereas only job resources was the driver of engagement. These results also supported by Gan and Gan (2014) which indicated that job demands were strongly correlated to burnout than engagement where job resources predicted both burnout and engagement. According to Sulea et al. (2012), job characteristics could be distinguished by job demands and job resources based on JD-R model. In their study, they included sample of 258 employees from three organizations in Romania to examine whether job resources i.e. POS, interpersonal conflict at work as job demands and personal resources such as conscientiousness might work as antecedents of work engagement. Results demonstrated that engagement anticipated by interpersonal conflict at work directly but negatively whereas POS and conscientiousness were positive predictors of engagement. Although many studies conceptualized job demands as a stressor had negative influence on engagement, Sawang (2012) identified job demands as a positive driver of work engagement among 307 IT managers in Australia which suggested that workers with high demand of work will engage them more, in contrary, undemanding work levels likely to be bored and disengaged.

Previous research has confirmed that job characteristics especially employees with more autonomy reports higher levels of engagement (Taipale et al., 2011; Slatten \& Mehmetoglu, 2011; Slattery et al., 2010). In line with these findings, $\mathrm{Xu}$ and Thomas (2010) argued that senior positions in organizations have greater autonomy which will make greater association with work engagement. They also suggested that leadership behavior namely relationship and task oriented behavior could affect engagement. Results of their study showed that leadership position, supports team, performs effectively and displays integrity had influence on engagement. On the other hand, Papalexandris and Galanaki (2009) worked on the leadership practices included good manager/mentor and vision articulation among 51 CEO's and their subordinates. Research found that good manager/mentor and articulating vision both were good predictors of engagement whether the CEO was entrepreneur or professional. Jorge and van Dierendonck (2014) cited on their article that servant leadership is the feelings that one wants to serve first. They conducted a research on 1107 people of two merging Portuguese companies and found that servant leadership had a positive significant relation to work engagement under a high uncertainty. Similar to this view, De Clercq et al. (2014) investigated servant leadership-engagement relationship in the context of Ukraine with a sample of 263 employees and suggested that employees who perceived higher level of servant leadership in their supervisor showed stronger engagement at their work. The study of leadership-engagement relationships has been accompanied by Zhang et al. (2014), within 439 retail employees in Australia. Results posited that visionary and organic leadership style had a positive association to engagement whereas transactional and classical leadership negatively related to engagement. Sarti (2014) examined 251 workers in Italy and identified that participative and instrumental leadership styles were significant predictor of engagement. Many authors also identified that transformational leadership had positive and significant impact on engagement in different context such as Australia, South Africa, Korea (Breevaart et al., 2014; Yasin et al., 2013; Vincent-Hoper et al., 2012; Hoon Song et al., 2012; Zhu et al., 2009). 
However, predictors of engagement were not limited to job characteristics (Parker \& Griffin, 2011). Gan and Gan (2013) recommended that incorporating the effects of personality would provide greater insight into the dynamic development of engagement. The purpose of their study was to examine the effect of personality trait i.e. neuroticism, extraversion and conscientiousness on engagement along with job characteristics. Findings indicated that extraversion and conscientiousness were positive but neuroticism was negative predictors of engagement. Similarly, Woods and Sofat (2013) also noted that engagement was highly influenced by assertiveness and industriousness and neuroticism had a negative impact on engagement in the perspective of 238 workers in UK. Kim et al. (2009) confirmed that conscientiousness was the strongest driver of engagement among all the five dimensions of personality traits. In addition, agreeableness was positive and neuroticism was negative antecedents of engagement.

In addition to job characteristics and personal traits, organizational level resources like Human Resource Management (HRM) practices are also vital antecedents of engagement as these practices are able to assist employees to accomplish their work and reduce job demands. Findings from a recent empirical study by Karatepe (2013) consisted 110 frontline employees from eight Romanian hotels demonstrated that HRM practices were significant predictors of engagement. Moreover, authors reported that individual perceptions of HRM practices may vary. Thus, Alfesa et al. (2013) pointed out that perceived HRM practices had significant positive impact on engagement. Suan and Nasurdin (2014) revealed that HRM practices specifically service training and performance appraisal had more significant association to work engagement among 438 hotel employees in Malaysia. Consistent with this view, another study done by Suan Choo et al. (2013) with a sample of 97 employees of electronics manufacturing firms in Malaysia. Findings of this study showed that employee development and reward \& recognition were the strongest antecedents of employee engagement but interestingly, employee communication had negative impact on engagement. Authors argued that if employees will not properly communicated the company messages may elevate pressure which may lead to disengagement. Azoury et al. (2013) revealed that compensation and psychological climate had significant association with work engagement but communication was insignificant in family and non-family firms. Scholars asserted that performance appraisal is one of the most important HRM practices as it is directly related to outcomes of the organization (Jawahar, 2007; Steensma \& Visser, 2007; Murphy \& Cleveland, 1995;). Volpone et al. (2012) suggested that by increasing transparency in the performance appraisal process may help to increase employee engagement. In this regard, Gupta and Kumar (2012) conducted a research on 323 professionals working in Indian private and public sector to explore the performance appraisal justice paradigms to employee engagement. Results of this study indicated that distributive justice and informational justice were the strongest drivers of engagement compare to procedural and interpersonal justice. Similarly, Agarwal (2014) also found that procedural and interactional justice were not significant predictors of engagement among the managers of manufacturing and pharmaceuticals firms in India. On the other hand, Strom et al. (2014) have identified that procedural and distributive justice positively related to work engagement under the conditions of low transactional leadership rather high among 348 employees in USA. To discover the predictors of employee engagement, Sharma and Sharma (2010) have focused on a set of HRM practices using a sample of 116 executives of manufacturing firms in India. Results showed that compensation and benefit, performance management, learning and development and job content were critical drivers of engagement.

In summary, previous studies examined diverse set of antecedents of employee engagement which can be categorized into organizational practices, job characteristics and personal traits. The above discussion showed that the relationship of different antecedents and employee engagement are varied for different studies, nature of organizations and countries which suggests the inconclusive findings of prior research on antecedents of employee engagement. In addition, these results also highlight the critical role of the nature of organization and country context in predicting the relationship of various antecedents with employee engagement.

\section{Consequences of Employee Engagement}

Although it is crucial to identify the antecedents that are expected to predict engagement, existing literature confirms that employee engagement has a positive outcomes for organizations as well. Harter et al. (2002) stated the significant role of employee engagement in business results. Thus, the following part discusses about the various consequences of employee engagement.

Several studies have identified that employee engagement is an important factor to foster employee performance and it has found that there is a positive correlation between engagement and employee performance (Mone \& London, 2014; Halbesleben, 2010). According to Saks (2006), employee engagement could affect business results through individual performance as engagement is an individual level construct. To examine the employee performance, Bakker et al. (2012) have tried to find out the impact of work engagement on job on a sample of 144 different occupational employees. Their findings suggested that high energetic and dedicated employees were more possibly to have sufficient task performance. In the same way, Shantz et al. (2013), based on 283 employees of consulting firms in UK, revealed that engagement leads to higher levels of task and 
citizenship performance where deviant behavior was the negative consequences of engagement. These findings were also true for the manufacturing firms in UK, pointed out that deviant behavior and intention to quit were the negative outcomes of work engagement (Shantz et al., 2014). Another study has been carried out by Alarcon and Edwards (2011) among 227 part-time employed students, demonstrated that engagement was an effective predictor of job satisfaction and turnover intentions. This study recommended that engaged employees may invest more resources such time and effort into the workplace which manifest job satisfaction. Schaufeli and Bakker (2004) argued that engaged employees are possibly have a lower intention to quit their organizations. According to Yeh (2013), with a high level of work engagement, frontline hotel employees could experience positive emotions in their workplace, directed to better job satisfaction.

In addition, there is some empirical research that has reported the relationships between engagement and work outcomes. For instance, Saks (2006) tested a model to examine the outcomes of engagement involving a sample of 102 employees working in different organizations in Canada. He reported that both job and organization engagement affects behavioral outcomes. In the line of Saks's (2006) findings, Andrew and Sofian (2012) also posited the similar work outcomes for both job and organization engagement involving 104 employees in Malaysia. However, Boon and Kalshoven (2014) accompanied a study on 270 supervisors to examine the impact of work engagement on OC. Results showed that engaged employees might highly committed to their organization. A cross-sectional study found the similar results among 595 academics in South African higher education institutions (Barkhuizen et al., 2014). Another study claimed that work engagement had both positive and negative consequences such as OC and job tension (Hansen et al., 2014). This study comprising a sample of 451 employees of an international firm in USA and Canada, described that high work engagement could mitigate the anxiety from organizational stressors at workplace, resulting low job tension and high commitment. Agarwal et al., (2012) highlighted the attitudinal and behavioral contributions that engaged employees make to organizations. They investigated 979 service sector employees in India, demonstrated that engaged employees would have positive emotions such as happiness, joy, interest and enthusiasm in their work and lead to a lower tendency to quit the job. Moreover, engaged employees encouraged organizational effectiveness by instituting discretionary innovative work behaviors. Similar findings have been revealed by a recent study of Agarwal, (2014) for manufacturing and pharmaceuticals firms in India, posited that innovative work behavior was a significant outcome of work engagement. Consequently, Slatten and Mehmetoglu (2011) also identified the close linked between employee engagement and innovative behavior among hospitality frontline employees in Norway. In fact, since frontline employees in service organizations are expected to deal with a number of customer requests which is important to have innovation in frontline jobs. Alfes et al., (2013), in a study of 1796 service sectors employees in the UK, similarly found that employee engagement had the positive significant association to innovative work behavior and task performance. In their study, Chughtai and Buckley (2011) concluded that higher level of engagement led to innovative work behavior and in-role job performance when associated with higher levels of learning goal orientation. Indeed, work engagement enhances employees learning attitudes that lead to high in-role job performance and innovativeness. It is also important to note that these findings were justified for the sample of 168 research scientists in Ireland. Bakker et al., (2012) showed, in their study among employees and their closest coworkers from a wide variety of organizations in the Netherlands, that work engagement made a unique contribution to explaining variance in in-role job performance. In line with these studies, Li et al., (2012) conducted a research, incorporating a sample of 298 employees and 54 supervisors working in Chinese hotels, posited that supervisors should involve in social exchange relationship with their subordinates to enhance the levels of engagement, consequently high job performance.

In another study, it was reported that work engagement has a positive influence on affective commitment and extra-role performance, and negative influence on turnover intentions for a sample of frontline employees in Iran (Karatepe, 2013). Empirically, Shuck et al., (2014) found that work engagement reduced turnover intentions among employees in health care industry. Furthermore, Albrecht and Andreetta (2011) confirmed the direct and indirect outcomes of work engagement by using a sample of 139 employees in a health service area. This study suggested that engaged employees will feel motivated and experience a sense of affective commitment in turn, they will be less inclined to entertain thoughts of leaving the organization. Collini et al., (2013) proposed that healthcare organizations in the USA were facing high nurses' turnover rate because of decreasing work engagement. Similarly, Schaufeli and Bakker (2004) identified that employee engagement had a negative influence on turnover intentions in the presence of job resources for a sample of 1698 employees from four independent occupations. They suggested that availability of job resources will help to reduce employees' job demands; consequently increases work engagement which in turn, reduces turnover intentions. A cross-lagged study of Yalabik et al., (2013) clarified that job performance was a positive and turnover intentions was a negative outcome of work engagement among 167 bank employees in the UK. This contention was supported for 297 employees in a service sector organization in the UK, asserted that employee engagement had negative impact on turnover intentions (Alfes et al., 2013). They also argued that enactment of positive 
behavioral outcomes such as organizational citizenship behavior was the consequences of engagement. Later, structural equation modeling by Zopiatis et al., (2014), posited the view that job involvement had a negative influence on turnover intention through $\mathrm{OC}$ and job satisfaction among 482 hotel employees in Cyprus. Further, they showed that job involvement was positively associated with both affective and normative OC and only with intrinsic job satisfaction rather extrinsic. In a more recent longitudinal study conducted in Australia, postulated that work engagement had a negative influence on both turnover intention and psychological strain (Timms et al., 2015). Another time-lag study of two weeks, incorporating data from 225 employees and 30 supervisors working in the hotels situated in Cyprus, empirically found that affective commitment and job performance were the outcomes of work engagement.

As highlighted by Karatepe (2013), it is important to assess the performances of frontline employees since they should attend the customers in challenging service desk and show proactive behaviors to adapt the specific situations. In this regard, this study considered 110 full-time employees working in Romanian hotels and reported that employees with high work engagement appeared to have a stronger relationship with job performance and extra-role customer service. In addition, Albrecht (2012) obtained that work engagement was positively related to OC and extra role behavior in presence of high job resources such as career development, autonomy, supervisory support and role clarity by using structural equation modeling of survey data gathered from 3437 employees of a large multi-national mining company. On the other hand, Sulea et al. (2012) divided extra role behaviors as positive emotions related to organizational citizenship behavior and negative emotions related to counterproductive behavior. This cross-sectional study, consisted a sample of 258 employees working in three different Romanian organizations, exposed that engaged employees were more likely to involve with OCBs rather than CWBs because they want to accomplish their jobs efficiently. Vincent-Hoper et al. (2012) carried out a research with a heterogeneous sample, including 530 women and 602 men working in different occupations, to examine the effect of work engagement on occupational success in gender diversity. Findings suggested that work engagement was positively related to all the dimensions of occupational success namely, career satisfaction, social success, career success. Indeed, the relationship between work engagement and career satisfaction was stronger for women than men. Consistently, Burke et al. (2009) postulated that the positive outcomes of work engagement were job and career satisfaction and psychological well-being based on sample of 309 hotel employees in China. Authors argued that engaged employees have more energy, are more job involved and have identified more strongly with their job. However, various researchers opined that organizational knowledge was the norm in an organization, as it sharpens the organizational competitive advantages in highly competitive environment. With this view, in their study, Hoon Song et al. (2012) showed the positive relationship between work engagement and organizational knowledge creation in the Korean business context. While Chen et al. (2011) found that work engagement was significantly related to knowledge sharing behavior, by investigating the data collected from 139 software employees working in two Chinese companies. Several research suggested that the presence of high levels of employee engagement enhances employee performance, team performance, service climate, life satisfaction, employee loyalty, personal accomplishment and psychological well-being, career commitment and adaptability (Hoon Song et al., 2014; Findley Musgrove et al., 2014; Innanen et al., 2014; Shuck and Reio, 2014; Lee et al., 2014; Anitha, 2014; Menguc et al., 2013; Karaa et al., 2013; Barnes and Collier, 2013). However, many scholars narrated that work engagement could mitigate the negative employee performance. For instance, Shuck and Jr., (2014) investigated the data of 216 health care employees from the USA, Canada and Japan and found that employee engagement had a negative influence on depersonalization and emotional exhaustion. The longitudinal study of Innstrand et al. (2012) identified that work engagement provided the lower levels of depression and anxiety after two years by examining the sample of 3475 employees working in eight different occupational groups with two-year time interval in Norway. Consequently, Soane et al. (2013) also posited that the absence rate could be reduced by increasing the levels of employee engagement.

In summary, previous studies suggested that employee engagement could be a key factor for the performance and success of an organization. Because employee engagement has potential impact on wide variety measures of organizational performance such employee retention, loyalty, productivity, customer satisfaction, reputation and stakeholders value (Bakker et al., 2007; Hallberg et al., 2007; Xanthopoulou, 2007; Hakanen et al., 2006; Salanova et al., 2005; Schaufeli and Bakker, 2004; Harter et al., 2002). Indeed, employee engagement leads to both individual outcomes (i.e. quality of people's work and their own experience of doing that work), as well as organizational-level outcomes (i.e. the growth and productivity of organizations) (Khan, 1992). However, prior discussion highlighted that the relationship between employee engagement and various types of outcomes are not consistent, which pointed out the need of further study. Moreover, these inconsistent results create ambiguity to understand to what extent the level of employee engagement contributes in enhancing diverse individual as well as organizational outcomes. 


\section{Mediating and Moderating role of Employee Engagement}

In prior two sections, this study has discussed about the antecedents of employee engagement and consequences of employee engagement respectively from various academic literatures. From that discussion, it is clear that antecedents are likely to have the influence on employee engagement and the level of employee engagement have some consequences. Thus, this is a rational expectation about the prior research focusing on the mediating effect on antecedents and consequences of the relationship. Following section discusses about the mediating role of engagement.

Researchers have noted earlier that there is a significant relationship between antecedents and engagement, and between engagement and their consequences. Further, scholars have studied on employee engagement and found the engagement as a mediating variable. For example, Alias et al. (2014) found that employee engagement mediated the relationship between talent management practices and employee retention by fulfilling the three conditions: firstly, talent management practices had a direct relation to employee retention, secondly, talent management had a positive impact on employee engagement and thirdly, employee engagement was positively related to employee retention. Similarly, Collini et al., (2013) found that engagement fully mediated the relationship between respect and turnover rates. However, another study carried out by Shuck et al. (2014) revealed that employee engagement partially mediated the relationship between perceived support for participation in HRM practices and intentions to turnover. Because, the relationship between predictor variable and dependent variable were not reduced to non-significance when the hypothesized mediator entered into the model. The structural equation modeling confirmed the mediating role of employee engagement where job resources had a positive impact on engagement and engagement was negatively related to turnover intentions (Schaufeli \& Bakker, 2004). In addition, Barkhuizen et al. (2014) showed that work engagement played a mediating role between job resources and OC. Recently, Lee et al. (2014) claimed that job and organization engagement worked as a mediator by illustrating their model in which internal branding positively affect job and organization engagement, and job and organization engagement had a positive significant impact on job satisfaction. These results were confirmed by a sample of 297 service sectors employees in the UK. Ram and Prabhakar (2011) investigated the mediating role of employee engagement between antecedents and consequences, and revealed that all the antecedents i.e. job characteristics, extrinsic and intrinsic rewards, procedural and distributive justice, perceiver organizational support and supervisory support had significant influence on employee engagement which in turn, affect job satisfaction, job involvement, organization citizenship behavior and intention to quit. Yalabik et al. (2013) surveyed 167 employees working in the UK bank, to test a model that postulated affective commitment and job satisfaction as the drivers of work engagement and job performance and intention to quit were the outcomes of work engagement. Indeed, this study claimed that employee engagement fully mediated the relationship between affective commitment, job satisfaction and job performance; and affective commitment and intention to quit but partially mediated for the link of job satisfaction and intention to quit. On the other hand, Boon and Kalshoven (2014) identified the relationship between high commitment HRM and OC was fully mediated by work engagement which was supported by a sample of 270 supervisor-employees dyads. Alfes et al. (2013) recommended that employee engagement fully mediated the relation between perceived HRM practices and organizational citizenship behavior whereas, partially mediated the effect of perceived HRM on turnover intention among 297 employees in a service sector organization in the UK.

In the academic literature, Saks (2006) documented that both job and organization engagement mediated the relationship between antecedents (i.e. job characteristics, POS, perceived supervisory support, rewards and recognition, procedural justice and distributive justice) and consequences including job satisfaction, OC, intention to quit and organizational citizenship behavior. Unlike Saks (2006), Musgrove et al. (2014) demonstrated that revenue enhancement emphasis had a significance influence on job and organization engagement, and both the engagement was positively related to service climate. Further, they noted that job and organization engagement worked as a mediator between the link of revenue enhancement emphasis and service climate. In addition, Slatten and Mehmetoglu (2011) observed 279 frontline employees and identified that employee engagement mediated the relationship between autonomy, strategic attention and role benefit, and innovative behavior. Employee engagement also fully mediated the relationship between interpersonal relationship i.e. leader-member exchange and innovative behavior but partially mediated for the link of leadermember exchange relationship and intention to quit (Agarwal et al., 2012). In addition, employee engagement was the mediator between predictors and outcomes variables. Li et al. (2012) noted that the relationship between leader-member exchange and job performance was fully mediated by work engagement. Further, Hoon Song et al. (2014) found that employee engagement fully mediate the relationship between learning organization culture and team performance in Korean organization settings. However, Yeh (2013) found that employee engagement partially mediated the relationship between tourism involvement and job satisfaction. In addition, a study by Anitha (2013) examined the impact of work environment, leadership, team and co-worker, training and career development, compensation, organizational policies, and workplace well-being on employee performance 
through the measure of employee engagement and found that though all of the variables were found to be the determinants of employee engagement, only the effect of work environment, leadership, team and co-worker relationship, and employee well-being on employee performance is mediated through employee engagement.

Figure 1: Conceptual Model

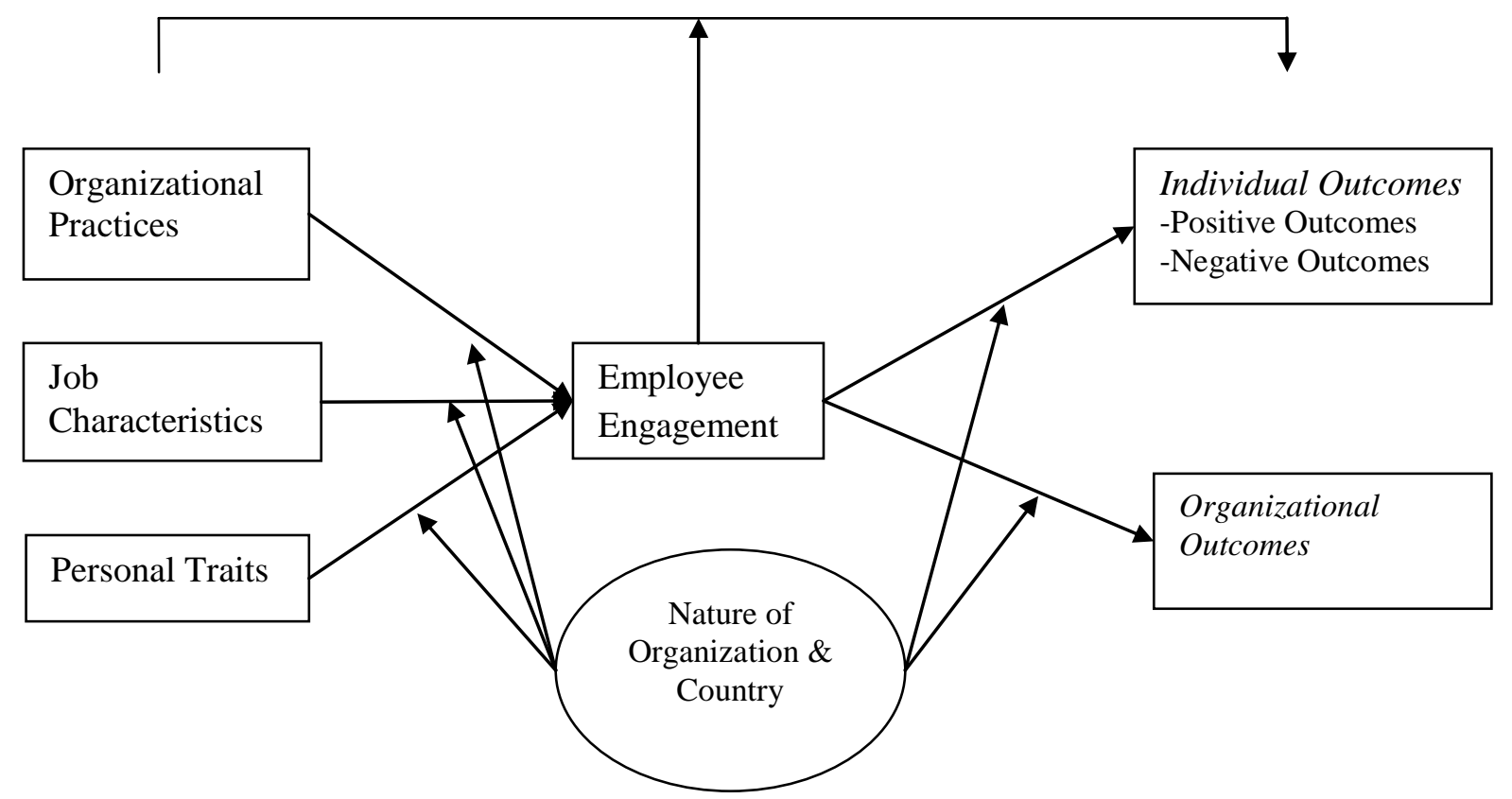

Furthermore, although several researches showed the mediating effect of employee engagement, in a more recent study empirically tested the moderating effect of employee engagement. In their study Shuck and Reio (2014) investigated 216 health care employees from the United States, Canada and Japan who were completed an online survey. The results of this study showed a significant relationship between psychological workplace climate and outcome variables such as: personal accomplishment, depersonalization, emotional exhaustion, and psychological well-being. Further, they also noted that employee engagement moderated the relationship between psychological workplace climate and each of the dependent variable.

\section{Conclusion and Implications}

The purpose of this paper is to synthesize prior literature to identify dynamic of research on employee engagement. This literature review concentrated mainly on the antecedents and consequences of employee engagement. The analysis of the existing literature indicates that prior researchers consider diverse types of antecedences as well as consequences to examine their relationship with employee engagement. Figure 1 presents summary of different antecedents and consequences of employee engagement. In addition, some of the research examined the mediating and moderating role of employee engagement in the relationship between antecedents and consequences of employee engagement. However, results of previous studies are varied for different antecedents, consequences, nature of business and context of the study. These inconclusive results highlight the need to further study to examine those relationships to magnify the understanding about the association of different antecedents and consequences of employee engagement. This paper has some critical implication of assisting future researcher, academics and managers to track the trend of employee engagement research as well as to provide a bird's eye view of the engagement research.

\section{Reference}

[1]. Agarwal, U. A., Datta, S., Blake-Beard, S., \& Bhargava, S. (2012). Linking LMX, innovative work behaviour and turnover intentions: The mediating role of work engagement. Career Development International, 17(3), 208-230.

[2]. Agarwal, U. (2014). Examining the impact of social exchange relationships on innovative work behaviour: Role of work engagement. Team Performance Management, 20(3/4), 102-120.

[3]. Albrecht, S. L. (2010). Employee engagement: 10 key questions for research and practice. The handbook of employee engagement: Perspective, issues, research and practice, 3-19.

[4]. Albrecht, S. L., \& Andreetta, M. (2011). The influence of empowering leadership, empowerment and engagement on affective commitment and turnover intentions in community health service workers: Test of a model. Leadership in Health Services, 24(3), 228-237. 
[5]. Albrecht, S. L. (2012). The influence of job, team and organizational level resources on employee well-being, engagement, commitment and extra-role performance: Test of a model. International Journal of Manpower, 33(7), 840-853.

[6]. Albrecht, S. L., Bakker, A. B., Gruman, J. A., Macey, W. H., \& Saks, A. M. (2015). Employee engagement, human resource management practices and competitive advantage: An integrated approach. Journal of Organizational Effectiveness: People and Performance, 2(1), 7-35.

[7]. Alderfer, C. P. (1972). Existence, relatedness, and growth: Human needs in organizational settings.New York, Free Press of Glencoe.

[8]. Alfes, K., Shantz, A. D., Truss, C., \& Soane, E. C. (2013). The link between perceived human resource management practices, engagement and employee behaviour: a moderated mediation model. The international journal of human resource management, 24(2), 330-351.

[9]. Alias, N., Noor, N., \& Hassan, R. (2014). Examining the mediating effect of employee engagement on the relationship between talent management practices and employee retention in the Information and Technology (IT) organizations in Malaysia. Journal of Human Resources Management and Labor Studiesi, 2(2), 227-242.

[10]. Anitha, J. (2014). Determinants of employee engagement and their impact on employee performance. International Journal of Productivity and Performance Management, 63(3), 308-323.

[11]. Azoury, A., Daou, L., \& Sleiaty, F. (2013). Employee engagement in family and non-family firms. International Strategic Management Review, 1(1), 11-29.

[12]. Bakker, A. B., Hakanen, J. J., Demerouti, E., \& Xanthopoulou, D. (2007). Job resources boost work engagement, particularly when job demands are high. Journal of educational psychology, 99(2), 274.

[13]. Bakker, A. B., Demerouti, E., \& Lieke, L. (2012). Work engagement, performance, and active learning: The role of conscientiousness. Journal of Vocational Behavior, 80(2), 555-564.

[14]. Bakker, A. B., \& Schaufeli, W. B. (2008). Positive organizational behavior: Engaged employees in flourishing organizations. Journal of Organizational Behavior, 29(2), 147-154.

[15]. Barkhuizen, N., Mogwere, P., \& Schutte, N. (2014). Talent Management, Work Engagement and Service Quality Orientation of Support Staff in a Higher Education Institution. Mediterranean Journal of Social Sciences, 5(4), 69.

[16]. Bates, S. (2004). Getting engaged. HR Magazine, 49, 44-51.

[17]. Biswas, S., \& Bhatnagar, J. (2013). Mediator analysis of employee engagement: role of perceived organizational support, PO fit, organizational commitment and job satisfaction. Vikalpa, 38(1), 27-40.

[18]. Boon, C., \& Kalshoven, K. (2014). How High-Commitment HRM Relates to Engagement and Commitment: The Moderating Role of Task Proficiency. Human Resource Management, 53(3), 403-420.

[19]. Breevaart, K., Bakker, A., Hetland, J., Demerouti, E., Olsen, O. K., \& Espevik, R. (2014). Daily transactional and transformational leadership and daily employee engagement. Journal of occupational and organizational psychology, 87(1), 138-157.

[20]. Brunetto, Y., Shriberg, A., Farr-Wharton, R., Shacklock, K., Newman, S., \& Dienger, J. (2013). The importance of supervisor-nurse relationships, teamwork, wellbeing, affective commitment and retention of North American nurses. Journal of Nursing Management, 21(6), 827-837.

[21]. Burke, R. J., Koyuncu, M., Jing, W., \& Fiksenbaum, L. (2009). Work engagement among hotel managers in Beijing, China: potential antecedents and consequences. Tourism Review, 64(3), 4-18.

[22]. Caesens, G., Stinglhamber, F., \& Luypaert, G. (2014). The impact of work engagement and workaholism on wellbeing: The role of work-related social support. Career Development International, 19(7), 813-835.

[23]. Chughtai, A. A., \& Buckley, F. (2011). Work engagement: antecedents, the mediating role of learning goal orientation and job performance. Career Development International, 16(7), 684-705.

[24]. CIPD (2006). Human Capital Evaluation - Evolving the Data. CIPD Human Capital Panel, CIPD, London.

[25]. Collini, S. A., Guidroz, A. M., \& Perez, L. M. (2013). Turnover in health care: the mediating effects of employee engagement. Journal of nursing management.

[26]. Chen, Z. J., Zhang, X., \& Vogel, D. (2011). Exploring the Underlying Processes Between Conflict and Knowledge Sharing: A Work-Engagement Perspective1. Journal of applied social psychology, 41(5), 1005-1033.

[27]. Choi, M. K. (2006). Development of internal branding performance measure and analysis on the difference of internal branding performances between local and international hotels. Korean Journal of Community Nutrition, 11(1), 116-123.

[28]. Czarnowsky, M. (2008). Learning's role in employee engagement: An ASTD research study. Alexandria, VA: American Society for Training and Development.

[29]. Demerouti, E., \& Cropanzano, R. (2010). From thought to action: Employee work engagement and job performance. Work engagement: A handbook of essential theory and research, 147-163.

[30]. De Clercq, D., Bouckenooghe, D., Raja, U., \& Matsyborska, G. (2014). Servant Leadership and Work Engagement: The Contingency Effects of Leader-Follower Social Capital. Human Resource Development Quarterly, 25(2), 183212.

[31]. Ferrer, J. (2005). Employee engagement: Is it organizational commitment renamed?

[32]. Unpublished working paper, Victoria University, Melbourne, Australia. Retrieved from

[33]. http://eprints.vu.edu.au/123/1/wp8_2005_ferrer.pdf

[34]. Gan, T., \& Gan, Y. (2014). Sequential development among dimensions of job burnout and engagement among IT employees. Stress and Health, 30(2), 122-133.

[35]. Gallup Consulting (2012). The Relationship Between Engagement at Work and Organizational Outcomes.Gallup Management Journal. 
[36]. Ghosh, P., Rai, A., \& Sinha, A. (2014). Organizational justice and employee engagement: Exploring the linkage in public sector banks in India. Personnel Review, 43(4), 628-652.

[37]. Goffman, E. (1961). Encounters: Two studies in the sociology of interaction.

[38]. González-Romá, V., Schaufeli, W. B., Bakker, A. B., \& Lloret, S. (2006). Burnout and work engagement: Independent factors or opposite poles?. Journal of Vocational Behavior, 68(1), 165-174.

[39]. Gruman, J. A., \& Saks, A. M. (2011). Performance management and employee engagement. Human Resource Management Review, 21(2), 123-136.

[40]. Gupta, V., \& Kumar, S. (2012). Impact of performance appraisal justice on employee engagement: a study of Indian professionals. Employee Relations, 35(1), 61-78.

[41]. Kahn, W. A. (1990). Psychological conditions of personal engagement and disengagement at work. Academy of management journal, 33(4), 692-724.

[42]. Kahn, W. A. (1992). To be fully there: Psychological presence at work. Human relations, 45(4), 321-349.

[43]. Lee, J. J., \& Ok, C. M. (2014). Understanding hotel employees' service sabotage: Emotional labor perspective based on conservation of resources theory. International Journal of Hospitality Management, 36, 176-187.

[44]. Hackman, J. R., \& Oldham, G. R. (1980). Work redesign. Reading, MA: Addison-Wesley.

[45]. Hakanen, J. J., Bakker, A. B., \& Schaufeli, W. B. (2006). Burnout and work engagement among teachers. Journal of school psychology, 43(6), 495-513.

[46]. Harter, J. K., Schmidt, F. L., \& Hayes, T. L. (2002). Business-unit-level relationship between employee satisfaction, employee engagement, and business outcomes: a meta-analysis. Journal of applied psychology, 87(2), 268.

[47]. Halbesleben, J. R. (2010). A meta-analysis of work engagement: Relationships with burnout, demands, resources, and consequences. Work engagement: A handbook of essential theory and research, 8, 102-117.

[48]. Hallberg, U. E., Johansson, G., \& Schaufeli, W. B. (2007). Type A behavior and work situation: Associations with burnout and work engagement. Scandinavian Journal of Psychology, 48(2), 135-142.

[49]. Hansen, A., Byrne, Z., \& Kiersch, C. (2014). How interpersonal leadership relates to employee engagement. Journal of Managerial Psychology, 29(8), 953-972.

[50]. Harter, J. K., Schmidt, F. L., \& Hayes, T. L. (2002). Business-unit-level relationship between employee satisfaction, employee engagement, and business outcomes: a meta-analysis. Journal of applied psychology, 87(2), 268.

[51]. Hewitt Associates LLC. (2004). Research brief: employee engagement higher at double-digit growth companies.

[52]. Hoon Song, J., Kolb, J. A., Hee Lee, U., \& Kyoung Kim, H. (2012). Role of transformational leadership in effective organizational knowledge creation practices: Mediating effects of employees' work engagement. Human Resource Development Quarterly, 23(1), 65-101.

[53]. Hoon Song, J., Hun Lim, D., Gu Kang, I., \& Kim, W. (2014). Team performance in learning organizations: mediating effect of employee engagement. The Learning Organization, 21(5), 290-309.

[54]. Innanen, H., Tolvanen, A., \& Salmela-Aro, K. (2014). Burnout, work engagement and workaholism among highly educated employees: Profiles, antecedents and outcomes. Burnout Research, 1(1), 38-49.

[55]. Innstrand, S. T., Langballe, E. M., \& Falkum, E. (2012). A longitudinal study of the relationship between work engagement and symptoms of anxiety and depression. Stress and Health, 28(1), 1-10.

[56]. Jawahar, I. M. (2007). The influence of perceptions of fairness on performance appraisal reactions. Journal of Labor Research, 28(4), 735-754.

[57]. Jorge Correia de Sousa, M., \& van Dierendonck, D. (2014). Servant leadership and engagement in a merge process under high uncertainty. Journal of Organizational Change Management, 27(6), 877-899.

[58]. Kara, D., Uysal, M., Sirgy, M. J., \& Lee, G. (2013). The effects of leadership style on employee well-being in hospitality. International Journal of Hospitality Management, 34, 9-18.

[59]. Karatepe, O. M. (2013). High-performance work practices and hotel employee performance: The mediation of work engagement. International Journal of Hospitality Management, 32, 132-140.

[60]. Keller, K. L. (2003). Building, measuring, and managing brand equity. International Edition, Peatson Edition.

[61]. Kim, B. P., Murrmann, S. K., \& Lee, G. (2009a). Moderating effects of gender and organizational level between role stress and job satisfaction among hotel employees. International Journal of Hospitality Management, 28(4), 612-619.

[62]. Kim, H. J., Shin, K. H., \& Swanger, N. (2009b). Burnout and engagement: A comparative analysis using the Big Five personality dimensions. International Journal of Hospitality Management, 28(1), 96-104.

[63]. Lee, Y. K., Kim, S., \& Kim, S. Y. (2014). The Impact of Internal Branding on Employee Engagement and Outcome Variables in the Hotel Industry. Asia Pacific Journal of Tourism Research, 19(12), 1359-1380.

[64]. Li, X., Sanders, K., \& Frenkel, S. (2012). How leader-member exchange, work engagement and HRM consistency explain Chinese luxury hotel employees' job performance. International Journal of Hospitality Management, 31(4), 1059-1066.

[65]. Macey, W. H., Schneider, B., Barbera, K. M., \& Young, S. A. (2009). Employee engagement: Tools for analysis, practice, and competitive advantage. John Wiley \& Sons.

[66]. Macey, W. H., \& Schneider, B. (2008). The meaning of employee engagement. Industrial and organizational Psychology, 1(1), 3-30.

[67]. Menguc, B., Auh, S., Fisher, M., \& Haddad, A. (2013). To be engaged or not to be engaged: The antecedents and consequences of service employee engagement. Journal of business research, 66(11), 2163-2170.

[68]. Maslach, C., \& Leiter, M. P. (1997). The truth about burnout: how organization cause, personal stress and what to do about it. San. rancisco: Jossey-Bass.

[69]. Maslach, C., Schaufeli, W. B., \& Leiter, M. P. (2001). Job burnout. Annual review of psychology, 52(1), 397-422. 
[70]. May, D. R., Gilson, R. L., \& Harter, L. M. (2004). The psychological conditions of meaningfulness, safety and availability and the engagement of the human spirit at work. Journal of occupational and organizational psychology, 77(1), 11-37.

[71]. Maslow, A. H., Frager, R., \& Cox, R. (1970). Motivation and personality (Vol. 2). J. Fadiman, \& C. McReynolds (Eds.). New York: Harper \& Row.

[72]. Mone, E. M., \& London, M. (2014). Employee engagement through effective performance management: A practical guide for managers. Routledge.

[73]. Murphy, K. R., \& Cleveland, J. (1995). Understanding performance appraisal: Social, organizational, and goalbased perspectives. Sage.

[74]. Parzefall, M. R., \& Hakanen, J. (2010). Psychological contract and its motivational and health-enhancing properties. Journal of Managerial Psychology, 25(1), 4-21.

[75]. Papalexandris, N., \& Galanaki, E. (2009). Leadership's impact on employee engagement: Differences among entrepreneurs and professional CEOs. Leadership \& Organization Development Journal, 30(4), 365-385.

[76]. Parker, S. K., \& Griffin, M. A. (2011). Understanding active psychological states: Embedding engagement in a wider nomological net and closer attention to performance. European Journal of Work and Organizational Psychology, 20(1), 60-67.

[77]. Ram, P., \& Prabhakar, G. V. (2011). The role of employee engagement in work-related outcomes. Interdisciplinary Journal of Research in Business, 1(3), 47-61.

[78]. Richman, A. (2006). Everyone wants an engaged workforce how can you create it? Workspan, 49, 36-39.

[79]. Robertson, I. T., \& Cooper, C. L. (2010). Full engagement: the integration of employee engagement and psychological well-being. Leadership \& Organization Development Journal, 31(4), 324-336.

[80]. Robertson, I. T., Jansen Birch, A., \& Cooper, C. L. (2012). Job and work attitudes, engagement and employee performance: Where does psychological well-being fit in?. Leadership \& Organization Development Journal, 33(3), 224-232.

[81]. Robinson, D., Perryman, S., \& Hayday, S. (2004). The drivers of employee engagement. Report-Institute for Employment Studies.

[82]. Robison, J. (2012, January 5). Boosting engagement at Stryker. Gallup Management Journal. Retrieved from http://gmj.gallup.com/content/150956/Boosting-Engagement-Stryker.aspx

[83]. Rothbard, N. P. (2001). Enriching or depleting? The dynamics of engagement in work and family roles. Administrative Science Quarterly, 46(4), 655-684.

[84]. Saks, A. M. (2006). Antecedents and consequences of employee engagement. Journal of managerial psychology, 21(7), 600-619.

[85]. Salanova, M., Agut, S., \& Peiró, J. M. (2005). Linking organizational resources and work engagement to employee performance and customer loyalty: the mediation of service climate. Journal of Applied Psychology, 90(6), 1217.

[86]. Sarti, D. (2014). Job Resources as Antecedents of Engagement at Work: Evidence From a Long-Term Care Setting. Human Resource Development Quarterly, 25(2), 213-237.

[87]. Sawang, S. (2012). Is there an inverted U-shaped relationship between job demands and work engagement: The moderating role of social support?. International Journal of Manpower, 33(2), 178-186.

[88]. Schaufeli, W. B., Salanova, M., González-Romá, V., \& Bakker, A. B. (2002). The measurement of engagement and burnout: A two sample confirmatory factor analytic approach. Journal of Happiness studies, 3(1), 71-92.

[89]. Schaufeli, W. B., \& Bakker, A. B. (2004). Job demands, job resources, and their relationship with burnout and engagement: A multi-sample study. Journal of organizational Behavior, 25(3), 293-315.

[90]. Schaufeli, W. B., Taris, T. W., \& Van Rhenen, W. (2008). Workaholism, burnout, and work engagement: three of a kind or three different kinds of employee well-being?. Applied Psychology, 57(2), 173-203.

[91]. Schaufeli, W. B., \& Bakker, A. B. (2010). Defining and measuring work engagement: Bringing clarity to the concept. Work engagement: A handbook of essential theory and research, 10-24.

[92]. Shantz, A., Alfes, K., Truss, C., \& Soane, E. (2013). The role of employee engagement in the relationship between job design and task performance, citizenship and deviant behaviours. The International Journal of Human Resource Management, 24(13), 2608-2627.

[93]. Shantz, A., Alfes, K., \& Latham, G. P. (2014). The Buffering Effect of Perceived Organizational Support on the Relationship Between Work Engagement and Behavioral Outcomes. Human Resource Management.

[94]. Sharma, Y., \& Sharma, B. R. (2010). Search for the Drivers of Employee Engagement among Executives of a Manufacturing Organisation. Management and Labour Studies, 35(2), 189-207.

[95]. Shuck, B., \& Wollard, K. (2010). Employee engagement and HRD: A seminal review of the foundations. Human Resource Development Review, 9(1), 89-110.

[96]. Shuck, B., \& Reio, T. G. (2011). The employee engagement landscape and HRD: how do we link theory and scholarship to current practice?. Advances in Developing Human Resources, 1523422311431153.

[97]. Shuck, B., \& Reio, T. G. (2014). Employee engagement and well-being a moderation model and implications for practice. Journal of Leadership \& Organizational Studies, 21(1), 43-58.

[98]. Simpson, M. R. (2009). Predictors of work engagement among medical-surgical registered nurses. Western journal of nursing research, 31(1), 44-65.

[99]. Slåtten, T., \& Mehmetoglu, M. (2011). Antecedents and effects of engaged frontline employees: A study from the hospitality industry. Managing Service Quality: An International Journal, 21(1), 88-107.

[100]. Slattery, J. P., Selvarajan, T. T., Anderson, J. E., \& Sardessai, R. (2010). Relationship between job characteristics and attitudes: A study of temporary employees. Journal of Applied Social Psychology, 40(6), 1539-1565. 
[101]. Soane, E., Shantz, A., Alfes, K., Truss, C., Rees, C., \& Gatenby, M. (2013). The Association of Meaningfulness, Well-Being, and Engagement with Absenteeism: A Moderated Mediation Model. Human Resource Management, 52(3), 441-456.

[102]. Steensma, H., \& Visser, E. (2007). Procedural justice and supervisors' personal power bases: effects on employees' perceptions of performance appraisal sessions, commitment, and motivation. Journal of Collective Negotiations, 31(2), 101-118.

[103]. Strom, D. L., Sears, K. L., \& Kelly, K. M. (2014). Work engagement the roles of organizational justice and leadership style in predicting engagement among employees. Journal of Leadership \& Organizational Studies, 21(1), 71-82.

[104]. Suan, C. L., \& Mohd Nasurdin, A. (2014). Do Human Resource Management Practices Affect Employees' ServiceOriented Organizational Citizenship Behavior? Evidence from the Malaysian Hotel Industry. World Applied Sciences Journal, 31(2), 253-266.

[105]. Suan, C. L., \& Nasurdin, A. M. (2013). Role clarity, supervisory support, peer support, and work engagement of customer-contact employees in hotels: A future research agenda. Tourisms: an international multidisciplinary journal of tourism, 8(1), 315-329.

[106]. Sulea, C., Virga, D., Maricutoiu, L. P., Schaufeli, W., Zaborila Dumitru, C., \& Sava, F. A. (2012). Work engagement as mediator between job characteristics and positive and negative extra-role behaviors. Career Development International, 17(3), 188-207.

[107]. Taipale, S., Selander, K., Anttila, T., \& Nätti, J. (2011). Work engagement in eight European countries: The role of job demands, autonomy, and social support. International Journal of Sociology and Social Policy, 31(7/8), $486-504$.

[108]. Timms, C., Brough, P., O'Driscoll, M., Kalliath, T., Siu, O. L., Sit, C., \& Lo, D. (2015). Flexible work arrangements, work engagement, turnover intentions and psychological health. Asia Pacific Journal of Human Resources, 53(1), 83-103.

[109]. Trinchero, E., Brunetto, Y., \& Borgonovi, E. (2013). Examining the antecedents of engaged nurses in Italy: Perceived Organisational Support (POS); satisfaction with training and development; discretionary power. Journal of nursing management, 21(6), 805-816.

[110]. Vincent-Höper, S., Muser, C., \& Janneck, M. (2012). Transformational leadership, work engagement, and occupational success. Career development international, 17(7), 663-682.

[111]. Volpone, S. D., Avery, D. R., \& McKAY, P. F. (2012). Linkages between racioethnicity, appraisal reactions, and employee engagement. Journal of Applied Social Psychology, 42(1), 252-270.

[112]. Wollard, K. K., \& Shuck, B. (2011). Antecedents to employee engagement a structured review of the Literature. Advances in Developing Human Resources, 13(4), 429-446.

[113]. Woods, S. A., \& Sofat, J. A. (2013). Personality and engagement at work: the mediating role of psychological meaningfulness. Journal of Applied Social Psychology, 43(11), 2203-2210.

[114]. Xanthopoulou, D., Bakker, A. B., Demerouti, E., \& Schaufeli, W. B. (2007). The role of personal resources in the job demands-resources model. International journal of stress management, 14(2), 121.

[115]. Ye, J., Marinova, D., \& Singh, J. (2007). Strategic change implementation and performance loss in the front lines. Journal of Marketing, 71(4), 156-171.

[116]. Yasin Ghadi, M., Fernando, M., \& Caputi, P. (2013). Transformational leadership and work engagement: The mediating effect of meaning in work. Leadership \& Organization Development Journal, 34(6), 532-550.

[117]. Yalabik, Z. Y., Popaitoon, P., Chowne, J. A., \& Rayton, B. A. (2013). Work engagement as a mediator between employee attitudes and outcomes. The International Journal of Human Resource Management, 24(14), 2799-2823.

[118]. Yeh, C. M. (2013). Tourism involvement, work engagement and job satisfaction among frontline hotel employees. Annals of Tourism Research, 42, 214-239.

[119]. Zhang, T., C. Avery, G., Bergsteiner, H., \& More, E. (2014). Do follower characteristics moderate leadership and employee engagement?. Journal of Global Responsibility, 5(2), 269-288.

[120]. Zhu, W., Avolio, B. J., \& Walumbwa, F. O. (2009). Moderating role of follower characteristics with transformational leadership and follower work engagement. Group \& Organization Management.

[121]. Zopiatis, A., Constanti, P., \& Theocharous, A. L. (2014). Job involvement, commitment, satisfaction and turnover: Evidence from hotel employees in Cyprus. Tourism Management, 41, 129-140. 